\title{
Geographical Indications: Eastern Partnership Countries case
}

\section{Natalia MOGOL ${ }^{1}$}

\begin{abstract}
In the Eastern Partnership (EaP) countries, the subject of geographical indications is particularly important. Although the approach to the subject of GIs in the EaP countries is uneven and differs from country to country, the attention that each of these states pays at the national level to the field of geographical indications cannot be neglect. In countries such as Georgia and Moldova, the development of the GI system is one of the national strategic objectives. This interest is largely due to those economic benefits offered by the implementation of the geographical indications system, especially in countries where the share of the agri-food sector in GDP is significant. Despite the fact that challenges regarding the implementation of the association agreement in the part concerning geographical indications in the EaP countries are quite similar, there are no complex studies regarding the implementation of the geographical indications systems in the Eastern Partnership Countries. The main purpose of this paper is to fulfill the existing gap and to analyze the current situation in the field of GI highlighting best practices but also the vulnerabilities of the GI system in the EaP countries.
\end{abstract}

Keywords: association agreement, eastern partnership, geographical indications, intellectual property, enforcement of geographical indications

JEL Code: O38, F15, K42

\section{Introduction}

2009 is the year in which the Republic of Moldova (MD), together with Ukraine (UA), Georgia (GE), Armenia (AM), Azerbaijan (AZ) and Belarus

\footnotetext{
${ }^{1}$ Natalia MOGOL, PhD in economic sciences, Deputy Director General of the State Agency on Intellectual Property of the Republic of Moldova. E-mail: natalia.mogol@gmail.com
} 
(BE) became part of one of the most ambitious European projects - the Eastern Partnership (EaP).

Officially launched on 7 May 2009 at the Eastern Partnership Summit in Prague, the project was conceived in the context of the 2004 EU enlargement, almost for the promotion of the European values at the political and economic level in jurisdictions concerned.

Over the past 12 years, thanks to the EaP, some Eastern European countries, such as Georgia, Ukraine and Moldova, have signed Association Agreements, which have allowed citizens of the Republic of Moldova, Ukraine and Georgia to travel without visas to the EU and trade without taxes. Armenia has signed a Comprehensive and Enhanced Partnership Agreement wich provides for more liberalization in commerce. Azerbaijan and Belarus are still at the stage of negotiations.

A significant feature of the bilateral agreements signed by EU in the last decades is that the intellectual property provisions, which they include often, provide for a higher level of protection than that which is required by TRIPS (e.g. supplementary protection of patents, protection of medical trials data, very high level of geographical indications (GIs) protection, etc.) (Blakeney, 2014).

The agreements applied between the EU and Georgia and Moldova since 2016, the Ukraine since 2017 and Armenia since 2021 are not an exception. Here is to mention that GE and MD has previously to AAs signed agreements on reciprocal recognition of GIs, applied for Georgia from April 1, 2012, and for MD from April 1, 2013. In both cases, those special GI agreements were incorporated in the AAs.

The Association agreements mentioned above provide for the establishement of the Deep and Comprehensive Free Trade Areas (DCFTAs) applied between the EU and Georgia and Moldova since 2016 and the Ukraine since 2017.

The DCFTAs have two key elements: trade liberalisation and regulatory approximation. Trade liberalisation (the 'free trade' component of the DCFTAs) means removing tariffs and reducing non-tariff barriers to trade in goods, services and investment, thus increasing market access for goods and services for both sides. The parties to each of the agreements regularly exchange information and monitor developments in trade. 
According to European Commission Report (2020), for all three DCFTA countries (GE, MD, UA), the EU became the biggest trading partner. Total trade with the DCFTA countries has overall slightly increased year by year, reaching $€ 50.6$ billion in 2019. EU-Ukraine bilateral trade has increased steadily in both directions and reached $€ 43.3$ billion in 2019. Ukraine is also the 4th largest exporter towards the EU of agriculture products. In 2019, the overall trade between the EU and Georgia decreased on a year-on-year-basis by 3\%, amounting to $€ 2.6$ billion and the total trade between the EU and Moldova grew by $3.9 \%$ compared to 2018 , to reach slightly over $€ 4.7$ billion.

Regulatory approximation is another of the 'deep and comprehensive' component of the DCFTAs. The EU partner countries commit to approximate their legislation to the EU legislation in a number of trade-related policy areas, such as sanitary and phytosanitary matters, technical specifications and standards (lowering technical barriers to trade), public procurement, services and customs procedures. The European Commission monitors the process, taking into account the development of the EU legislation in the areas covered by the Association Agreement/DCFTA

In the context of the embargoes imposed by the Russian Federation, in particular to the Republic of Moldova and Ukraine, the Eastern Partnership States have reoriented their trade policies towards the Community market, and with this, they have started to implement EU product quality standards, including specific quality schemes, namely geographical indications systems.

\section{Literature review}

There are a quite wide range of works dedicated to geographical indications system (e.g. Calboli, 2015; Blakeney, 2014; Abbott, Cottier \& Gurry, 2019; Kireeva \& O'Connor, 2010; WIPO Handbook, 2017) and also there are certain interesting researches regarding the implementation of the association agreements between European Union and particular EaP countries (e.g. Kawecka-Wyrzykowska, 2015; Kyryliuk, Mekshun \& Polkovnychenko, 2017; Mogol, 2014; Oliinyk, Baranovych, \& Akhtimirova, 2018).

However, despite the fact that challenges regarding the implementation of the association agreement in the part concerning geographical indications in the EaP countries are quite similar, there are no complex studies regarding 
the implementation of the geographical indications systems in the Eastern Partnership Countries.

The main purpose of this paper is to fulfill the existing gap and to analyze the current situation in the field of GI highlighting best practices but also the vulnerabilities of the GI system in the EaP countries.

This research focuses on the provisions of the agreements concluded between the $\mathrm{EU}$ and the $\mathrm{EaP}$ countries, in particular chapters relating to geographical indications, but also the national regulatory framework of Belarus, Armenia, Azerbaijan, Georgia, Moldova and Ukraine, in this particular field.

\section{Data and Methodology}

The aim of this paper is to compare the $\mathrm{EaP}$ countries practices regarding the implementation and development of the geographical indications protection system.

Thus, the Paper is based on the research of the available regulatory framework in the field of intellectual property focusing particularly on geographical indications.

It includes the comparative analysis of the current situation and of the evolution of the national GI systems, as well as the impact of the Association Agreements on the status quo in this particular field.

\section{The system of geographical indications' in the Eastern Partnership States}

Examining the current situation, we can divide the 6 states of the Eastern Partnership into two groups:

- Group of WTO Member States (AM, GE, MD, UA)

- Group of non-WTO member states (AZ, BY) with observer status

The group of WTO Member States is certainly distinguished by a more comprehensive legal framework in the field of reference. This is mainly due to the fact that the protection of geographical indications is mandatory for

\footnotetext{
' In the context of this study, the notion of geographical indication will be frequently used to cover the notion of designation of origin, unless the notions will be used separately.
} 
WTO Member States as provided for in the Agreement on Trade-Related Intellectual Property Rights (TRIPS).

Therefore, unlike BY and AZ where GI protection is provided for in trademark protection laws and is assimilated to the latter, in AM, GE, MD and UA there are special laws that expressly provide for the protection of geographical indications being also provided for the differentiation between the two related concepts: geographical indication (GI) and designation of origin (DO). Among the mentioned states, there are AM and MD that have practically transposed the community legislation in this field in the national legislation. MD went even further, unlike Community legislation, Law on appellation of origin, geographical indications and traditional specialities guarantee 2008 (Moldova) does not contain any restrictions on the nature of products that can benefit from protection through the quality system cited (AM, expressly excluded mineral waters as ineligible for protection as GI).

Although harmonised, the legal framework of the EaP states in the field of GIs slightly differs from the Community system in several aspects, in particular,

1) Regarding definitions each of the examined countries applies different definitions of GIs and AOs, some (MD, AM) limits it to names, others (GE) opens the definition of GIs to signs, but the most specific are the definitions provided by the Law on the Protection of Rights to Indication of Origin of Goods 2019 (Ukraine) which provides a very explicit subordination between the GIs and AOs:

Geographical indication - appellation of origin" identifying a product originating from certain geographical place and having special quality, reputation or other characteristics stemming mainly from this geographical place of origin, preserving that at least one of the stages of this product's manufacture (production (extraction) and/or processing and/or preparation) takes place in a certain geographical area;

Appellation of origin - a type of geographical indication meaning the name identifying a product originating from a certain geographical place and having special qualities or properties stemming, solely or mainly, from particular geographical environment with natural and human factors characteristic for this geographical place, if all stages of this product's

\footnotetext{
" In some jurisdictions the term appellation of origin is used instead of the designation of origin, without affecting the essence and the scope of the rights
} 
manufacture (production (extraction) and/or processing and/or preparation) take place in a designated geographical area;

2) Regarding who can apply in $\mathrm{AM}$ and $\mathrm{MD}$, the legislation provides that only an association regardless of its organizational and legal form can initiate the process of recognizing a geographical indication. In UA, only in 2020 the law was modified and a specific provision on the group's right to apply was introduced. Before 2020, the law of Ukraine on the Protection of Rights to Indication of Origin of Goods expressly defined the applicant as any person or group of persons who has filed an application for registration of a geographical indication.

In the context of the above, it is to be mentionned that in Ukraine in the case of the overwhelming majority of the 16 DOs and 5 local GIs for mineral waters, cheeses, wines, handicrafts, the protection was requested by a single legal entity.

Another specific practice regarding who can apply is that of Georgia, where Law on Appeals of Origin and Geographical Indications of Goods 1999, art. 2 (d), (Georgia) defines the applicant as: a natural or legal person, public authority or legal person under public law, voluntary association of entrepreneurs, regardless of the organizational-legal form, which requires the right to register a designation of origin or geographical indication and / or the right to use a designation of origin or geographical indication.

Probably, for this reason in Georgia, most of the 34 designations of origin and 21 local geographical indications for wines, mineral waters, cheeses, etc. are registered in the name of the Ministry of Agriculture of Georgia.

The registration of a geographical indications in the name of a single legal person or a public authority can be jeopardized by several factors, the most important of which is that the geographical indication system was built as a collective, optional and voluntary system which involves the establishment by a group of producers (future users of the protected geographical indication) of clear rules which they undertake to comply with when producing the PGI product.

Whereas if a certain producer or the State initiates the GI registration process without consulting the opinion of all or at least a significant part of the producers involved in the production of the GI product, the rules will be established unilaterally without consulting all interested parties, which in principle may lead to a lack of interest from producers in promoting and fully 
exploiting the GI, but also in insufficient motivation to comply with the provisions of the specifications.

That is why, although to register a GI in the name of a single private company or a public authority is a short cut to preservation and protection of important national symbols such as GIs are, it shall constitute merely an exception than a rule.

3) regarding the validity of the right, in contrast to BY and AZ laws, where the regime of GI registration's validity is identical to trademarks, i.e. the established term of validity of the registration of geographical indication is 10 years from the date of the application for registration, in AM, UA, MD and GE, the validity of the GI registration is unlimited, is conditionned only by the preservation of the special conditions. But, interestingly, in Armenia the validity of the right to use the geographical indication is set at 10 years.

The Law on Geographical Indications 2010, art. 13 (2) (Armenia) provides that the right to use the protected geographical indication or designation of origin shall be entitled for a period of ten years. This date can be extended for no more than ten years for every single time, provided the technical requirements of that particular product are met.

In UA, GE and MD the right to use is conditionned only by the fullfilment of the technical specification's requierements.

4) regarding official controls, esspecially in the part of the correspondence of GI products with the requirements of the specifications the weak link in all EaP countries. It is generally recognised that only by implementing rigurous control mechanisms it is possible to ensure a credible GIs system, but even at the EU level there are different approaches to this subject (e.g. France with a very sophisticated control system and Poland where the State Agency on Food Safety is merely responsible for the official control). Due to the complexity of this issue, the experience of EaP countries is not uniform. We have on one hand BY and AZ, where there is no official control provided in the special laws, on the other hand MD, UA, AM with very explicit provisions on official controls and GE in the middle with an indirect refference to official controls in the special law. At this stage any EaP country with a perfectly functional control system, could be detected. However, there are areas that can be delimited as an example in this regard. For example, the wine field 
in $\mathrm{MD}$, where due to a professional management provided by the National Office of Vine and Wine, traceability from grapes to wine bottles is ensured.

There are many other areas where EaP countries shall harmonise their legislation in the field of GIs in order to align to EU standards, but those mentionned are the most important.

Of course the issue of harmonization of the legislation in the field of GIs is an ongoing one and is more relevant for those $\mathrm{EaP}$ countries that signed special agreements with EU or Agreements that contains special provisions on GIs.

\section{Enforcement of the EU GIs in Armenia, Georgia, Moldova and Ukraine}

An important aspect of the implementation of the geographical indications system is the enforcement of GI rights. GI enforcement is the core issue in the respective section of the Bilateral Agreements.

In accordance with the provisions of the examined Bilateral Agreements the Parties shall enforce the protection provided for in corresponding articles of the Agreements by appropriate administrative actions or legal proceedings, as appropriate, including at the customs border (export and import), in order to prevent and stop any unlawful use of the protected geographical indications. They shall also enforce such protection at the request of an interested party (AA EU-MD, 2014, AA EU-UA, 2017, AA EU-GE, 2014).

A key provision of the EU bilateral agreements regarding geographical indications is ex officio protection, which provides that the public authorities has to actively monitor the market for breaches.

The high level of protection provided under bilateral agreements with the EU is a challenge for the signatory states, in particular because, as a result of their entry into force, they are obliged to ensure the protection of more than 3700 EU GIs.

Protective measures are materialized in, but not limited to:

1) Prevention of trademark registration of EU GIs infringing signs, usually realised by intellectual property offices.

Case Laws:

Ucraine

The Ukrainean legislation defines the "champagne of Ukraine" as the individual category of goods with specific characteristics. That is why upon 
discussion of the list of the geographical indications of the European Union, the transition period has been established for the geographical indications. According to Oliinyk et al. (2018) at a time when local wineries understood that they would be limited in the use of the name "Champagne" for the sparkling wines, they sought another attractive name for the sparkling wines. The name "Asti" suited well for this purpose. Thus, the local winery NYVA located in the Tairove, Odessa region (southwestern province of Ukraine), launched the new product TAIROVO ASTI combining the well-known ASTI DOCG (Denominazione di Origine Controllata e Garantita) with the name of the Tairove village, Odessa region. To support the right to use this name, before the UA-EU AA came into force, a series of trademarks were registered with ASTI DOCG, including TAIROVO ASTI (Latin \& Cyrillic), SALUTE ASTI (Latin \& Cyrillic) for sparkling wines in class 33.

At the same time, the prosecution's records of the trademarks by the examining authority and by the Chamber of Appeals of the Ministry of Economic Development and Trade of Ukraine indicate that since signing the EU-Ukraine Association Agreement and its entering into force as of 1 September 2017 the situation totally changed. Namely, by the decision of the Chamber of Appeals of the Ministry of Economic Development and Trade of Ukraine (hereinafter the "Chamber of Appeals") on 7 September 2017, issued in respect of the application no. $\mathrm{m} 201517110$ ASTI\&dev., a refusal decision. The case, first of all, illustrates an attempt for registration of the ASTI name in the name of the Italian Consortium which mimics the Consortium for the Promotion of Asti (Consorzio per la Tutela dell'Asti), but has nothing to do with the said Consortiumin an attempt to circumvent the grounds for refusal of the legal protection.

2) Prevent the use of similar signs in the internal market by administrative measures involving authorities such as competition authorities, food safety agencies, etc.

Case laws:

Ukraine

In 2012, the Antimonopoly Committee of Ukraine (the AMCU) issued a decision with regard to "Zvenigorodsky Cheese Factory" LLC, in which the Ukrainian company's actions were found to be a violation of the law on protection from unfair competition in the form of dissemination of misleading 
information. The AMCU found that this company produced and sold melted cheese of its own production named "Sandwich cheese with Parmesan" while its composition lacked "Parmesan" (Oliinyk, Baranovych, \& Akhtimirova, 2018).

Republic of Moldova (Case no. 22h-131/18)

In 2015-2016 National Food Safety Agency (NFSA) of the Republic of Moldova detected substantial batches of wine marked with GI Prosecco protected on the territory of the Republic of Moldova based on AA. The consignments were intended for export mainly to the Russian Federation. NFSA seized the lots, banning their sale. The economic agent challenged the actions of the NFSA inspector, claiming that he owns rights to the Prosecco Pronto trademark.

Background: Application for the trademark, PROSECCO PRONTO, filing number 035942, applicant Bulgary Winery S.R.L., Republic of Moldova. The rejection decision was issued on 17.07.2015 based on the geographical indication PROSECCO.

The producer Bulgary Winery SRL from the Republic of Moldova argued in favor of registering its trademark by the fact that Prosecco is the name of a vine variety that was planted by the producer on its land to be used for the production of sparkling wines.

The counter-arguments put forward by Consorzio di tutela della denominazione di origine controllata Prosecco, Piazza Filodrammatici, 3, I31100 Treviso (TV), Italy, focused on the fact that the variety name was replaced by GLERA in order to protect geographical indication and the replacement happened before the planting of the variety by the Moldovan producer. Moreover, Bulgari Winery did not object to the protection of GI Prosecco under AA and started using the name Prosecco commercially using graphic symbols that would increase the risk of confusion.

The decision of the District Court was a controversial one, it stated: the Prosecco brand is "generic on the territory of the Republic of Moldova in relation to "champagne", sparkling wine". Also, the court considered that AGEPI should reject the application for registration of the trademark IR 1169551, because it contravenes the national legislation, namely the provisions of art. 7 lit. c) and d) of Law no. 38 of 29 February 2008 on trademark protection, due to the fact that Prosecco is a name of a vine variety. 
The decision was subsequently canceled on appeal, and the Court of Appeal decided the case in favor of AGEPI and the Consorzio di tutela della denominazione di origine controllata Prosecco.

Bulgari Winery tried, later on, to register the PROS and ECCO trademarks separately, first directly and second through a related company. The application 038105 PROS was rejected based on the opposition submitted by Consorzio di tutela della denominazione di origine controllata Prosecco. Application no. 038130 ECCO, although initially rejected for lack of distinctiveness, obtained protection following the Decision of the AGEPI Appeals Commission.

3) Prevention of breaches of AAs commitments regarding GIs at customs borders in both directions (import and export) through the Customs Services.

Border measures are particularly important because the main flow of alcoholic beverages (wines, sparkling wines and brandy) with infringing names are destinated to exports, mainly to Russian Federation. In Russian Federation the names коньяк, кагор, шампанское are considered as generic names for the respective category of product. Moreover, according to labeling regulations the product category name shall be indicated on the label. Russian consumer does not understand that "pastoral wine", coming from Moldova is the same as "кагор wine". Important issue is that according to trade agreements applicable in the Commonwealth of Independent States (AM, AZ, $\mathrm{BY}, \mathrm{KZ}, \mathrm{KG}, \mathrm{MD}, \mathrm{RU}, \mathrm{TJ}, \mathrm{UZ}$ ), the custom duties imposed at the importation into Russian Federation to product category "коньяк" are lower than the custom duties imposed for the product category "brandy".

A particular challenge of implementing EU Bilateral Agreements in the part relating to geographical indications is determined by the fact that the list of EU GIs includes some indications that securing rights is particularly difficult.

Traditionally, from the Soviet era, the local vineyards used some geographical indications protected in the European Union as the generic names for different categories of goods, like "champagne" instead of "sparkling wines", "cognac" for "brandy", and the like. For Moldova and Georgia, the challenge of implementing the association agreement is not so prominent because both countries are party to the Lisbon Agreement. The situation is different in Ukraine and Armenia. 
As it can be observed, from the four EaP countries which are WTO members, only Armenia did not sign an Association Agreement, but a Comprehensive and Enhanced Partnership Agreement (CEPA). Obviously, it is not only because of the GIs, but certainly GIs are a very sensitive issue in the EU-AM negociations.

Particularly, Armenian economy is very dependent on the production of alcoholic beverages which are mostly exported to Russian Federation. Taking into account the soviet inheritance, Armenian producers use as generic term GI Cognac for designating high quality Armenian brandy and GI Champagne for sparkling wine produced in Armenia.

Thus, EU offered to Armenia a phase-out of the use of the geographical indication (GI) "Cognac" for products originating in Armenia, in line with Article 237 CEPA.

For a transitional period of 24 years after the entry into force of this Agreement for "Cognac" and for a transitional period of three years after the entry into force of this Agreement for "Champagne", the protection pursuant to this Agreement of those geographical indications of the European Union shall not preclude those names from being used on products originating in the Republic of Armenia and exported to third countries, where the laws and regulations of the third country concerned so permit, in order to designate and present certain comparable products originating in the Republic of Armenia, provided that:

(a) the name is labelled exclusively in non-Latin characters;

(b) the true origin of the product is clearly labelled in the same field of vision: and

(c) nothing in the presentation is likely to mislead the public as to the true origin of the product.

But, for the purposes of facilitating the smooth and effective termination of the use of the European Union geographical indication "Cognac" for products originating in the Republic of Armenia, as well as assisting the industry of the Republic of Armenia in maintaining its competitive position in export markets, the European Union shall provide to the Republic of Armenia technical and financial assistance. That assistance, to be provided in conformity with EU law, shall include, in particular, actions 
for developing a new name and promoting, advertising and marketing the new name in domestic and traditional export markets.

The issue is very sensitive because the economy of Armenia is largely affected by the possibility to use the transcription in Cyrillic of the denomination Cognac for the exports of the Armenian brandy, particularly to Russia. Another issue is the requirement to include a reference to "cognac" in Cyrillic and other non-Latin alphabet languages on the label of Armenian brandy when exported to Eurasian Economic Union members.

Some similar experience had Moldova in late 90's, before acceding to WTO and becoming member of the Lisbon Agreement. That time, at the political level it was decided to stop the use of particular EU GIs and to replace them by alternative names as it is represented below (Table 1).

Despite the fact that the implementation of alternative names affected Moldovan producers, after 20 years we can say with certainty that problems remained only for two of the seven names, namely Cognac and Cahors.

The Cahors case is particularly sensitive. In the Republic of Moldova, a very popular wine is a sweet red desert wine, which traditionaly was sold under the product category "кагор". In all Christian EaP and in some EU countries (Bulgaria, Poland, etc.) “кагор” is used especially during religious rituals and Easter Holydays. The name "кагор" is considered as an evocation of the AO CAHORS, protected in the Republic of Moldova by virtue of Lisbon Agreement on the protection of appelations of origin (1958) and AA EU-MD (2014) for dry wines. According to Moldova's obligations the wines bearing "кагор" on the label are prohibited. But producers are very dissatisfied, because products bearing "кагор" on the label are present in the EU market and even produced in some EU countries. Proof of this, together with the questions Do "кагор" constitute an evocation of the PDO CAHORS? Shall this be prohibited? was addressed by Moldovan side to EU within the fifth reunion of the MD-EU GI Subcomitee in 2019, but was not yet answered till today (Joint Minutes of the sixth EU-MD sub-committee on geographical indications, 2020).

In line with CEPA provisions, Armenia shall start the process of replacement of the name Cognac and totally replace it even for exports in third countries within 24 years from the date into entry of the CEPA. Also, in line with its CEPA obligations, the use of the name "Champagne" should be 
fully phased out (including in non-Latin characters) for Armenian products within the prescribed terms (Joint Minutes of the EU-AM partnership committee in trade configuration, 2019)

Table 1: Moldova's experience on replacing the protected geographical indications used as a generic term.

\begin{tabular}{|c|c|c|c|c|}
\hline PDO/PGI & $\begin{array}{c}\text { Product } \\
\text { category for } \\
\text { which } \\
\text { PDO/PGI is } \\
\text { applied }\end{array}$ & $\begin{array}{l}\text { Name used in } \\
\text { USSR, (cyrillic } \\
\text { with } \\
\text { transliteration) }\end{array}$ & $\begin{array}{l}\text { Alternative } \\
\text { name } \\
\text { implemented } \\
\text { in MD }\end{array}$ & $\begin{array}{c}\text { Product } \\
\text { category to } \\
\text { which } \\
\text { alternative } \\
\text { name is applied }\end{array}$ \\
\hline CHAMPAGNE & Wine & $\begin{array}{c}\text { Шампанское } \\
\text { (shampanskoe) }\end{array}$ & Spumant & Sparkling wine \\
\hline COGNAC & Wine spirit & $\begin{array}{l}\text { Коньяк } \\
\text { (coniac) }\end{array}$ & Divin & $\begin{array}{c}\text { Matured wine } \\
\text { distillate }\end{array}$ \\
\hline CAHORS & Wine & Кагор (cagor) & Pastoral & $\begin{array}{l}\text { Red and pink } \\
\text { dessert wines }\end{array}$ \\
\hline PORTO & $\begin{array}{c}\text { Generous } \\
\text { wine (liqueur } \\
\text { wine) }\end{array}$ & $\begin{array}{l}\text { Портвейн } \\
\text { (portvein) }\end{array}$ & Prometeu & $\begin{array}{l}\text { Wine heated } \\
\text { with O2 access } \\
\text { in minimum } \\
\text { doses }\end{array}$ \\
\hline XÉRÈS & Wine & Xepec (heres) & Ialoveni & Pellicular wine \\
\hline MADEIRA & Wine & $\begin{array}{l}\text { Мадера } \\
\text { (madera) }\end{array}$ & Luceafăr & $\begin{array}{l}\text { Heat-treated } \\
\text { wine with } \mathrm{O} 2 \\
\text { access in } \\
\text { excessive doses }\end{array}$ \\
\hline SAUTERNES & Wine & $\begin{array}{l}\text { Сотерн } \\
\text { (sotern) }\end{array}$ & Nectar & $\begin{array}{l}\text { White dessert } \\
\text { wines }\end{array}$ \\
\hline MARSALA & Wine & $\begin{array}{l}\text { Марсала } \\
\text { (marsala) }\end{array}$ & Cărpineni & $\begin{array}{c}\text { Caramelized } \\
\text { wine }\end{array}$ \\
\hline
\end{tabular}

Source: Munteanu, S. (2016, Octobre 27-28) Accord entre l'UE et la Republique de Moldova, 4ème Séminaire International d'Antalya sur les Indications géographiques Indications Géographiques en Turquie et dans les autres pays Méditerranéens: Tendances, Défis et Perspectives d'avenir, Antalya-Turquie

Due to common soviet inheritance, the UA faces similar challenges. Thus, advantageous UA measures have been negotiated and UA-EU Association Agreement expressly provides for certain transitional periods. Particularly, art. 208 of the UA-EU Association Agreement provides:

For a transitional period of 10 years from the entry into force of this Agreement, the protection pursuant to this Agreement of the following geographical indications of the EU Party shall not preclude these geographical 
indications from being used in order to designate and present certain comparable products originating in Ukraine: (a) Champagne, (b) Cognac, (c) Madera, (d) Porto, (e) Jerez /Xérès/ Sherry, (f) Calvados, (g) Grappa, (h) Anis Português, (i) Armagnac, (j) Marsala, (k) Malaga, (1) Tokaj.

For a transitional period of seven years from the entry into force of this Agreement, the protection pursuant to this Agreement of the following geographical indications of the EU Party shall not preclude these geographical indications from being used in order to designate and present certain comparable products originating in Ukraine: (a) Parmigiano Reggiano, (b) Roquefort, (c) Feta.

Although the Republic of Moldova is a signatory to the Lisbon Agreement, a transitional rule has been introduced in the text of the MD-EU Association Agreement regarding the granting of a 5-year period to bring the regulatory framework in line, in particular with regard to GI rights enforcement measures.

Without prejudice to the Republic of Moldova's previous commitments to grant protection for the Union geographical indications derived from international agreements on the protection of geographical indications and the enforcement thereof, including the commitments undertaken in the Lisbon Agreement for the Protection of Appellations of Origin and their International Registration, and in accordance with Article 301 of this Agreement, the Republic of Moldova shall benefit from a transitional period of five years from 1 April 2013 to put in place all complementary actions necessary to stop any unlawful use of the protected geographical indications, in particular the measures at the customs border.

Georgia did not negotiate any transitional measures for GI protection.

\section{The impact of GI protection under bilateral agreements: advantages and disadvantages}

At the time of signing, the balance of mutual protection of GIs in bilateral agreements signed by the Eastern Partnership States with the EU was clearly in favor of EU Member States, and it will probably remain like this in the future. However, it can be emphasized that all these bilateral agreements provide for the possibility for the Contracting Parties to add new GIs to be protected. In line with this provision, at the moment of signature of the bilateral agreements on GI protection between MD and EU, the EU forwarded 
a list of 3500 GIs. Meanwhile the list was completed with over 200 new EU GIs, thus constituting in 2021 over 3700 EU GIs. Same situation is in GE and UA. But same provision is applicable to GE, MD, UA GIs. On signature of the bilateral agreements on GIs protection between MD and EU, the MD forwarded only 2 GIs. Meanwhile the list was completed with other 6 new MD GIs and continue to be completed on a current basis.

The bilateral agreements allow producers from Georgia, Moldova, Ukraine and Armenia to protect, on the territory of the European Union, geographical indications registered at national level without incurring any costs on their part. The protection is ensured on the basis of the exchange of lists at specialized committees (for comparison to ensure the protection of a trade mark at Community level is charged a fee of approximately 900 Euro and representation by accredited persons is also required which also involves significant costs). At the same time, the savings made by the EU states for the protection of GIs in the Eastern Partnership states are not to be neglected. For example, to register those over 3700 GIs only in the Republic of Moldova, through the national procedure, it would have been necessary to pay over 900000 Euros official fees, not to mention related fees for legal assistance.

Noticing such an imbalance between the number of GIs in the EU's Eastern Partnership States protected and the EU GIs protected in the Eastern Partnership States involuntarily, the question arises who benefits from this exchange of lists?

For sure, from the point of view of GI protection EU bilateral agreementss are very advantageous for EU. We agree with Engelhardt (2015), affirming that advanced protection of European GIs represents an alternative strategy to maintain European market shares throughout the world, which can, at the moment, be achieved best through bilateral and regional agreements.

On the other hand, as mentionned before by some authors (e. g. Kawecka-Wyrzykowska, 2015), AAs as a whole offers a number of advantages to GE, MD and UA, although some of them are of an unquantifiable character and some will appear only in the longer term. First, the implementation of the AA will stabilise the internal economic and legal systems, making domestic laws more predictable and more difficult to reverse, thereby contributing positively to the long-term development of the countries. To put it differently, an AA with a major partner such as the EU is 
a signal to investors both at home and abroad that economic reforms will not be reversed, as they are guaranteed by a legally binding international agreement. This will increase the attractiveness of $\mathrm{EaP}$ as economic partners for foreign investors.

GI protection could actually result in increasing competition and innovation in the market and it should not be neglected. In particular, the recognition of GIs can force outside producers "to develop innovative techniques to improve upon a product to compete vis-a-vis the [GIdenominated] product category.' According to Calboli, 2015, it was precisely after Australia conceded to EU pressure and ceased to use several terms protected as GIs in the EU (deemed to be generic in Australia) that the wine industry in Australia truly grew because Australian producers started to invest in local names, which became symbols of excellent wines worldwide. Likewise, the U.S., a country notoriously anti-GI protection, has long enforced strong protection for appellation of wines due to the relevant business interests of California and other wine-making regions.

\section{Conclusions}

GI protection is a very sensitive issue. For countries as Moldova, Georgia, Ukraine and Armenia the promotion and development of geographical indications will contribute to the recognition of the local products both on local and on the export markets.

Especially this is important in the context of exporting GI products to the Community market which allocates considerable amounts of money annually to the promotion of the GI system and to consumers who are extremely interested in products of specific origin and quality.

After a thorough analysis of the situation in the field of GIs in the Eastern Partnership countries, the following main impediments for the development of the system of geographical indications might be delimited:

- Low level of awareness of the system of geographical indications both private and public;

- Insufficient promotion of the concept of product with geographical indication, so that the average consumer does not know the advantages offered by products with protected geographical indication; 
- Sophisticated and sometimes non-transparent GI recognition procedures;

- Lack or inefficiency of existing official control systems;

- Difficulty in undertaking some combined collective actions on the part of both the authorities and the producers (it is difficult for us to work in a team);

- Insufficient level of PGIs enforcement.

In order to overcome those challenges some actions shall be undertaken:

1. Regarding the legal framework, more legislative harmonization is needed in the upcoming years. In all the analyzed states, the official control system of the correspondence of GI products with the requirements of the specifications is the weak link, in this sense both training of existing bodies and the creation of premises for the emergence of private control bodies shall be undertaken in order to establish a credible official control system. In addition, because the registration of a GI is subject to the payment of fees, at least during the establishment of the system the exemption (according to the Community model) or at least partial (according to national experiences) payment of fees for the registration of a geographical indication would be a good step forward;

2. Regarding the institutional framework, that most often it is too complex. Usually, a group of producers shall interact with, at least 4 different authorities (1 - group registration, 2 - technical specification approval, 3 - GI registration, 4 - control of compliance of the product with technical requierements, 5 - market surveillance authorities, 6 - border measures, etc.). It would be great to find solutions in order to simplify the procedures (e.g. to find solutions in order to merge some procedures, like steps 1-3);

3. One of the key actions that should be taken in all countries analyzed is to promote the system of geographical indications so that public authorities and producers but also the average consumer understand that a product with a protected geographical indication is a product that has an origin and a guaranteed quality that offers advantages to each of the economic actors:

- Manufacturers obtain an efficient mechanism for product differentiation and at the same time customer loyalty; 
- Consumers gain access to a credible quality system guaranteed by the manufacturer and by the state;

- The state benefits from the quantitative and value increase of the consumption of domestic products.

Also, very important is the uderstanding that Association Agreement with the European Union is not an end in itself and is not a guarantee of success on its own. Without a strong commitment to develop economic, institutional and political fields, none of Moldova, Georgia, Ukraine or Armenia will succeed. For this purpose, the fulfillment of the assumed obligations is a crucial one and GIs sector is not an exception.

\section{References}

Abbott, F.M., Cottier, T., Gurry, F., (2019), International Intellectual Property in an Integrated World Economy, Fourth Edition, ISBN: 9781454895831

Association Agreement between the European Union and the European Atomic Energy Community and their Member States, of the one part, and the Republic of Moldova, of the other part (2014).

Association Agreement between the European Union and the European Atomic Energy Community and their Member States, of the one part, and the Ukraine, of the other part (2017).

Association Agreement between the European Union and the European Atomic Energy Community and their Member States, of the one part, and the Georgia, of the other part (2014)

Blakeney, M. (2014). The protection of geographical indications: law and practice, Elgar Intellectual Property Law and Practice.

Calboli, I. (2015), Geographical Indications of Origin at the Crossroads of Local Development, Consumer Protection and Marketing Strategies, IIC, International Review of Intellectual Property and Competition Law, 46, 760-780

(Case no. 22h-131/18) Consorzio di tutela della denominazione di origine controllata Prosecco vs. Bulgari Winery

http://agepi.gov.md/sites/default/files/litigii/decisions/trademarks/pro secco_hot_CSJ_27_06_2018.pdf

Comprehensive and enhanced partnership agreement between European Union and the European Atomic Energy Community, of the one part 
and the Republic of Armenia, of the other part (2020) https://www.mfa.am/filemanager/eu/CEPA_ENG_1.pdf

Engelhardt T. (2015), Geographical Indications Under Recent EU Trade Agreements, IIC (2015) 46,781-818, Published online: 27 October 2015, Max Planck Institute for Innovation and Competition, Munich, https://link.springer.com/article/10.1007/s40319-015-0391-3

European Commission Report (2020), Report on Implementation of EU

Trade Agreements, 1 January 2019 - 31 December 2019 https://trade.ec.europa.eu/doclib/press/index.cfm?id=2211

Kireeva, I. \& O'Connor, B. (2010), Geographical Indications and the TRIPS Agreement: What Protection is Provided to Geographical Indications in WTO Members?, The Journal of World Intellectual Property, 13(2), 275-303.

Kyryliuk, Yu. V., Mekshun, L. M., Polkovnychenko, S. O., (2017). Peculiarities of implementation of economic and trade parts of the Ukraine-European Union Association Agreement, Scientific Bulletin of Polissia, 12(4), 110-114.

Joint Minutes of the sixth EU-MD sub-committee on geographical indications, 19 october 2020

https://trade.ec.europa.eu/doclib/docs/2021/march/tradoc_159460.pd $\mathrm{f}$

Joint Minutes of the EU-AM partnership committee in trade configuration, 17 October 2019 , https://trade.ec.europa.eu/doclib/docs/2019/november /tradoc_158480.pdf

Kawecka-Wyrzykowska, E. (2015), The EU-Georgia Association Agreement: An Instrument To Support The Development Of Georgia Or Lip Service? / Układ Stowarzyszeniowy Ue - Gruzja: Instrument Wsparcia Rozwoju Gruzji Czy Deklaracja Bez Pokrycia, Comparative Economic Research, 2082-6737

Law on the Protection of Rights to Indication of Origin of Goods 2019 (Ukraine)

Law on Geographical Indications 2010 (Republic of Armenia)

Law on Appellations of Origin and Geographical Indications of Goods 1999 (Georgia)

Law on the protection of geographical indications, designations of origin and traditional specialties guaranteed 2008 (Republic of Moldova)

Mogol N., (2014). Evaluation of the perspectives of the system of geographical indications in the Republic of Moldova, Intellectus 2014(3), 38-48. 
Munteanu, S. (2016, Octobre 27-28) Accord entre l'UE et la Republique de Moldova, 4ème Séminaire International d'Antalya sur les Indications géographiques Indications Géographiques en Turquie et dans les autres pays Méditerranéens: Tendances, Défis et Perspectives d'avenir, Antalya -Turquie

Oliinyk, K., Baranovych, M., and Akhtimirova, M., (2018). Protection of EU Geographical Indications in Ukraine EU-Ukraine Association Agreement and Other Available Tools, European Food and Feed Law Review, 13(3), 241 - 249

WIPO Handbook, (2017) Introduction to intellectual property, theory and practice, second edition. 